\title{
Electronic Maps and Atlases in the Russian State Library and the Russian National Library
}

by NATALIA KOTELNIKOVA \&LUDMILA KILDUSHEVSKAJA

Within a brief span of time, maps on CD-ROM and on the Internet have become the most effective means of paperless information transfer. Map departments of the national libraries have found themselves up against the reality of needing to give readers access to electronic maps, which is possible only if they have a representative selection of electronic materials available in stock. It is a matter for regret that the Russian market is new being deluged with both licensed and unlicensed maps and atlases on CD-ROM. There are pirate copies of Russian and foreign publications alike. There are thus grave and almost insuperable difficulties to face when stocking electronic map libraries.

Two issues are to be highlighted on this score:

1. Acquisition of Russian maps on CD-ROM.

2. Acquisition of foreign maps on CD-ROM.

Due to the importance of collecting each country's published materials, the libraries are exerting efforts for the receipt of deposit copies of electronic publications. The firms „Informregister" and „Integral“, acting in the capacity of archival institutions, have now been entrusted with this function. They do not provide users with electronic copies.

To alter the current practice, a working group made up of representatives of archives, scientific and technical bodies, libraries, and lawyers has been set up, attached to the committee on culture of the State Duma of Russia. It is to make amendments to the Federal law on legal deposit. If these amendments go through, national libraries will be invested with the functions of gathering, keeping and placing publications on CD-ROM at users' disposal. They will select scientifically important electronic publications for their holdings and pass over those not in accord with the acquisition policy to other libraries. 
In Russia control of electronic maps gives rise to grave anxiety; we are having a hard time forming an opinion on the repertory of electronic maps, and so one can only make a sketchy outline of how this process will continue.

Russian digital cartography is developing in disregard of financial and departmental problems. A series of state and commercial institutions making geoinformation systems and electronic maps have arisen. The agencies constituting the system „Roskartografia“, the "Gosgistsentr" included (the Russian government geographical information centre), have made a great contribution to drawing electronic maps. They discharge the following functions: reception, registration, random control of digital topographic maps and plans, manufacture of copies of digital topographic maps, recurrent control of digital topographic maps, and taking orders from users for digital topographic maps.

Setting up the central stock of digital cartographic data within the purview of the Roskartografiya has marked a significant step in gathering digital cartographic information. Materials transmitted by regional geo-information hubs come together there. The stock comprises 144 nomenclature sheets on the scale of 1:1,000,000 and 3,495 sheets on the scale of 1:200,000. The necessary topographic maps are to be had both in the central and regional stocks. Users are given maps in the formats FIM, F20, DXF+DBF, in the exchange formats ARC/INFO which facilitates the handling of digital topographic maps (Pleshkov, 1997). The Russian national libraries carry no digital topographic maps since they are kept by the central stock of the Gosgistsentr and require a huge machine memory that is beyond the powers of the libraries.

Private firms are manufacturing interesting products. In the main they are making computer city maps, complete with enormous reference and information material. They are digitizing subject maps too. Thus the firm AGR „Geocentre" has digitized geological maps on the scale of 1:200,000.

The second issue involves stocking national libraries with foreign maps and atlases on CD-ROM. These come in as gifts and purchases. On the whole they are general geographic and thematic atlases, geological maps made by the US geological service, views of the Earth from outer space.

Electronic materials available in map departments are placed at readers disposal. They can be divided into several groups:

1. CD-ROM: multi-media geographic encyclopedias with vast quantities of maps Geopedia (Great Britain), Encarta (USA) general geographic and complex atlases, Rand McNally reference atlas (USA), the Russian version 
of the atlas Rand McNally Millenium World, ArcAtlas, Our Earth (USA), Danmark Topografisk Atlas, general geographic maps of Russia, of its individual parts and city maps; there are compact disks depicting portions of it, for example a plan of Nevski Prospekt, the main street in St. Petersburg. The plan contains background information on all buildings.

Many readers still lack sufficient experience in handling electronic publications; special directions are being drawn up to help them.

2. Electronic maps kept in the memory of personal computers in reading rooms.

3. Access to the electronic resources on the Internet.

Map departments in major libraries go in for creating their own electronic resources. The programme of establishing electronic map libraries calls for making digital copies of the most valuable parts of holdings, which allows access to them by distant users. This undertaking is still in its infancy, the necessary equipment has been bought, and the staff are getting experience with technologies and operating methods.

Some cartographic publications are presented on the web site of the Russian national library. Displayed there are some of the most interesting items from exhibitions. Russian maps dating from the 18th century are found on the Internet under the „Gabriel“ project (treasures of European libraries). Scanning maps for the joint Russo-American project „Meeting the frontiers" has started now. The project aims to create a joint site between the Russian national library, the Russian state library and the American Library of Congress focusing on the discovery and exploration of Siberia, Alaska and Western America. It is to include a good many maps, engravings, photographs and other pictorial items.

In league with a Finnish publishing house, the Russian national library has compiled a CD-ROM of maps of Finland from the 17th century onwards, and a similar edition treating Scandinavia is under preparation. Another disk dealing with maps and engravings from Peter the First's day has also been published.

By way of making electronic resources available to readers, the national libraries have drawn up methodological recommendations, the „Bibliographic description of electronic resources" (1997), and have begun to draw up the national standard on describing electronic resources, which will include 
examples of descriptions of electronic maps. Besides this, Russia has issued the national standard, Gost P51353-99 „Geo-information mapping. Metadata of electronic maps. Composition and content" (1999), developed by the 29th research institute of the Russian War Ministry.

This is how the map departments of the Russian national libraries are involved in using electronic maps in their work with readers. It is a positive aspect of their activities. However, large additional resources are required for managing, preserving, and passing on data, staff need to be trained anew as their duties change, and it renders the departments' work more difficult.

\section{REFERENCES}

Bibliographicheskoe opisanie electronnih resursov: Metodicheskie recomendacii.M., RGB, 1997.- 29 S.

GOST P51353-99. Geoinformacionnoe kartographirovanie. Metadannie electronnih kart. Sostav i soderzhanie.- M.: Gosstandart Rossii, 1999.- 7 S.

Pleshkov V.G., Centralniy fond cifrovih kartographicheskih dannih Roskartographii // Informacionniy bulleten GIS Associacii.- M., 1997, No. 5 (12).- S. 32 